\title{
A mélyhútött szuburbanizációtól a globalizáció csapdáin át a regionális tudomány igazságkereséséig Interjú Enyedi György akadémikussal
}

\section{From deep-frozen suburbanisation, via the traps of globalisation, to the truth-seeking role of regional science Interview with the academician György Enyedi}

A beszélgetés apropója a most megjelent tanulmány, amelyben Professzor Úr újragondolja, újraértelmezi a városnövekedés szakaszait. Miért éppen ehhez a témához nyúlt vissza, mi indokolta a témaválasztást?

Amikor hatvanéves koromban visszavonultam az RKK föigazgatói poszttól - amit elöre eldöntöttem -, úgy véltem, a hatvanas éveim már a bölcsesség, a szintézisek évei lesznek, és valami nagy monográfiát fogok írni a tapasztalataimról. Nem írtam meg, meg kell vallani, mert ez az időszak egybeesett a rendszerváltozással, és nagyon sok új feladatot kaptam az MTA-n belül, azután az UNESCO-nál, s ezek igazán érdekeltek. Azután, amikor már ezektől is visszavonultam, akkor gondoltam, hogy megint nekiveselkedek, hogy egy szintézist megírjak a modern urbanizációról, ami a legutóbbi nagyobb témám volt.

Maga ez a városnövekedésszakasz-elméletem közel 30 éves, azóta sok minden történt, bizonyos újragondolás és korrigálás indokolt lehet. A tanulmány inkább gondolatébresztő részemről, az eltelt több mint negyed évszázad alatt már lehet tudni, milyen irányba fejlődött tovább az utolsó városnövekedési szakasz, amit én az informatika korszakának neveztem.

Lehet-e ma már arról beszélni, hogy bizonyos urbanizációs jelenségek, folyamatok másként alakulnak, mint azt látni lehetett 20-30 évvel ezelött?

Az egyik meglepetés a számomra az volt, hogy korábbi föltételezésem, mely szerint a technika és az informatika fejlődése lehetővé teszi a települések szétszóródását, hiszen a munkahelyeknek nem kell a városokba tömörödniük, „nem jött be”. A megavárosok szaporodása, a nagyvárosi térségek létrejötte, egy bizonyos fajta területi koncentráció azóta történt meg, hogy először leírtam a városnövekedés szakaszait. Települési szinten a gazdasági döntéshozók és a

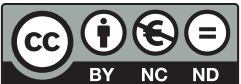


high tech számottevő szerepe a nagyvárosi régiókba tömörül. Jóllehet, technikailag lehetne a General Motors székhelye Lajosmizsén is, de nem megy oda, hiába jók ott az adottságok, sőt még amerikai kisvárosokba sem megy, hanem sokkal inkább betelepül a legnagyobb megalopoliszokba.

Jelen tanulmányában az urbanizáció negyedik szakaszát a globalizált világ urbanizációjaként definiálja. Professzor Úr továbbra is ellenáll a reurbanizációnak?

A reurbanizációt soha nem fogadtam el. Eredetileg jó harminc éve holland és angolszász szerzők fogalmazták meg, és a városközpont rehabilitációját, újranépesedését értették rajta. Azért neveztem én dodonai módon a globalizáció szakaszának a negyedik urbanizációs szakaszt, mert ez nem a régi városok újranövekedését hozta a fejlett országokban. Új jelenség, hogy igazi nagyvárosi, metropolisz térségek jönnek létre úgy, hogy a városok kiterjednek, túllépik a régi agglomerációs zónájukat. Ezenközben a központi nagyváros népessége tovább csökken!

\section{Mi az alapvető különbség a nagyvárosi régió és az agglomeráció között?}

A nagyvárosi régió annyiban tér el a nagyvárosi agglomerációtól, hogy míg ez utóbbi egyközpontú, a környékről ingavándorlás irányul a központba, addig az előbbi esetében mind a munkahelyek, mind a vonzáskörzetek földrajzilag különböző helyeken jelennek meg. Azt hiszem, ez a legmarkánsabb megjelenése a cluster network society-nek, vagyis a hálózatok társadalmának. Itt az emberek nincsenek röghöz kötve, hanem hálózatokban élnek. A részben a munkához, részben a gazdasághoz, részben a pihenéshez kötődő emberi kapcsolatok nagyon sajátos hálóval szövik át a metropolisz-régiókat.

Ha jól értem, akkor ez a jellemző struktúrájú nagyvárosi térbeli terjeszkedés az érintett falusi települések funkcionális újragondolását is eredményezheti?

A különcségem nemcsak az, hogy nem fogadom el a reurbanizációt, hanem úgy vélem, amikor a városi térség továbbterjeszkedik, az már területileg lazább szövetü, és ahogy kiterjed, társadalmilag is integrál falusi térségeket. Ezeken a falusi településeken az agrárfunkció feltétlenül megmaradhat, csak végre le kéne számolni azzal a szemlélettel, amely állandóan visszatér, s amely mezőgazdaságon valami elavult konstrukciót, kisgazdaságot, hegyesre pödört bajuszú bácsikákat ért modern agrárvállalkozók helyett. Ma már a nagyvárosi régiókba integrálódik az a falu, amely modern mezőgazdaságot folytat, mert azt csak falun lehet folytatni. Viszont ezek már sokfunkciójú falvak, ahol egymás mellett megférhet az agrártevékenység, az üdülőfunkció, a városban dolgozók egy részének lakóterülete, meg a várost szolgáló ipartelep.

Nem eldöntött dolog, hogy ha az emberek kistelepülésre mennek élni, akkor mezőgazdasággal kell foglalkozniuk. Előnyt nyújt a falun élés, és hátrányokat jelent, mindenki mérlegelheti, hogy melyik van túlsúlyban, melyiket választja. Akinek a falun élés nem jelent társadalmi kirekesztést és hát- 
rányt, csak kényelmetlenségeket, annak a fejében vannak kellemességek, például a természethez közeli élet. Egyébként a falu-város szakadék NyugatEurópában már a hatvanas évektől feltöltődőben és kiegyenlítődőben van.

\section{Mindez igaz Magyarországra is?}

A falu-város szakadék Magyarországon megmaradt a rendszerváltozásig, és a rendszerváltozás óta csak a dinamikus városi térségek környékén enyhült igazán. Ugyanakkor ez a szakadék kitágult a jól ismert krízisvidékeken, Északkelet-Magyarországon vagy a Délnyugat-Dunántúl egyes részein.

Tősgyökeres fơvárosiként hogyan látja az urbanizációs szakaszok érvényesülését Budapesten és a budapesti nagyvárosi térségben?

Először is Közép- és Kelet-Európában a szuburbanizáció mélyhütött állapotban volt az államszocialista rendszerben. A rendszerváltozás után nagyon gyorsan újraindult, s az egyik gondot éppen az jelentette, hogy úgy kezdődött meg a gyors népességnövekedés, hogy az ehhez kapcsolódó infrastruktúra nem alakult ki. A kilencvenes években nagyon rövid időszak volt, hogy ez az agglomerációs övezet jelentette az első olcsó munkaerőzónát a feldolgozóipar kitelepedéséhez. Most már nem Magyarország kínálja az olcsó munkaerőt, és nagy kérdés a jövőre nézve, hogy Közép- és Kelet-Európa országai mit tudnak nyújtani a K+F-szektorban és a technológiafejlesztésben. Mindez hatással lehet a városnövekedés következő hullámára a térségben.

Érzékelhetók-e már az elmúlt évek gazdasági válságának hatásai a magyar nagyvárosokban vagy éppen Budapesten?

Többfajta hatás is volt a városokban, köztük például az építkezések jelentős lelassulása. Azután olyan érdekes hatás is volt, hogy már a jelenlegi devizahitelek előtt szintén többen elveszítették lakásukat, elszegényedtek, hosszan munkanélküliek voltak. Ők azok, akik budapesti lakásukat el tudták adni, vagy a budapesti rehabilitációs területeken kártérítésként a komfort nélküli, szoba-konyhás lakásukért kaptak kisebb összegeket. Közülük aztán így elég sokan megjelentek a szegény vidékeken, pl. Hajdú-Bihar megyében, ahol viszont egész nagyméretű házat tudtak venni, bár természetesen munkanélküliek maradtak ott is. Ez egyébként a válság egyik sajátos mellékterméke, de nem törvényszerü és nem tartós folyamat.

Mi a fó oka annak, hogy a Professzor Úr által másfél évtizede a magyar gazdaság területi fejlődésére felvázolt három lehetséges szcenárió közül a legrosszabb, a polarizált térségi fejlődés vált valóra, ami az ország szétszakadását eredményezte?

Akkor még nem kalkuláltam be a hosszú távú előrejelzéseimbe a globalizációnak ezt a nagy erejét. Azzal sem számoltam, hogy ilyen erőteljes lesz a feltörekvő gazdaságok világgazdasági jelentősége. Vagyis Magyarország nem tud jó politikával és olcsó munkaerővel számottevő ipart vonzani a tér- 
ségbe. Abban az időben az indiai iparról nem is tudtunk eleget, a kínai iparról pedig az olcsó tömegcikkek jutottak eszünkbe, és senki nem tudta, hogy 16 év múlva már a számítógépekkel jönnek elő, $s$ technikailag igényes tömegtermeléssel árasztják el olcsón a világot.

Ez azt jelenti, hogy feltételezésünk, mely szerint a viszonylag iskolázott magyar munkaerő - mivel alacsonyabb bérért is hajlandó dolgozni - az elmaradottabb vidékekre nagyobb mértékben vonz külföldi befektetőket, megint „nem jött be”.

És még egy dolog, amire nem gondoltam akkor, hogy a fejlett régióink - Budapest és környéke vagy Nyugat-Magyarország - is kemény nemzetközi versenyben vannak. Budapest erősítése nemzeti érdek, ha tetszik, mert versenyben van a nemzetközi nagyvárosok között. Ha veszít, akkor az nagy veszteség, de ha támogatjuk a Nyugattal való versenyben, akkor megint nincs lehetőség az országon belüli kiegyenlítődésre.

Nevezhetjük globalizációs csapdának azt, hogy a globalizációs kihívásoknak való megfelelés kényszerüen együtt jár az országon belüli regionális különbségek növekedésével?

$\mathrm{Az}$ országokon belüli kiegyenlítődést mint területfejlesztési célt is gyengíti a globalizáció és az európai integráció. A kilencvenes évek elején - még nemzetállamokban gondolkodván - én még nem érzékeltem, még nem láttam, hogy az Európai Unión belüli versenyben, egy nagy gazdasági térségen belüli versenyben kénytelenek leszünk erősíteni a mi erős pontjainkat, ami viszont a gyönge pontjaink hátrányát növeli.

Szóval, hol az igazság mostanában? Se itt, se máshol, de azért folyton keressük.

Van-e szerepe a regionális tudománynak ebben az igazságkeresésben?

Hogyne, de ez inkább az európai kultúrkörhöz kötődik, hisz itt Európában nehezen toleráljuk, hogy egyes társadalmi csoportok, régiók, falvak kiesnek a normális életmenetből. Ázsiában nincs ilyen típusú érzékenység, Ázsiában az elesetteket a család támogatja.

Alapvetően ök másként is értelmezik a globalizációt.

Úgy értelmezik, hogy a legtöbb hasznot kell kivenni belőle. Például Kínában az egyenlőtlenség város és falu között csak annyiban izgatja most a kínai gazdaságpolitikát, hogy a faluról való túl nagy bevándorlást kell valahogyan tolerálnia a városoknak. Talán nem véletlen, hogy a két leglátványosabban fejlődő, és a világban legnagyobb szerepet játszó gazdaság a legrégebbi városi kultúrák tere. Ezekben az országokban nagyon régi a hagyománya, hogy teret szervezzenek, hogy a terek együttműködését tervezzék, hogy regionális léptében gondolkozzanak, fejlesszenek, fejlődjenek. 
Mennyire keltette fel a nemzetközi jelenségek, globális kérdések vizsgálata a magyar regionális tudomány érdeklődését?

A regionális kutatás eredményeinek alkalmazott jellege - ami Magyarországon különböző okokból kifolyólag eléggé általános - egy kicsit befelé fordít, a hazai és a környező problémák megoldására koncentrál. Úgy gondolom, a fiatalabb generáció nagymértékben érdeklődik a globális kérdések iránt. Jó nyelvtudással és nyitott szemmel belátta, hogy nem csak Magyarországon él. Felismerte: hogy hogyan él Magyarországon, az nem annyira itt dől el, hanem nagyobb térségekben.

Talán egy bizonyos provincializmusba zökkent a magyar regionális tudomány, de kifelé jön belőle. Elég csak arra gondolni, hogy a Regional Studies Association eddigi legsikeresebb kongresszusát Pécsett rendezte 2010-ben, s nemcsak azért, mert Pécs Európa kulturális fővárosa volt. A Regionális Kutatások Központja mutatott olyan tudományos erőt, ami ide tudta vonzani ezt a 600 fös konferenciát.

Az interjút Uzzoli Annamária készítette 2011. január 26-án. 